GEOGRAFICKÝ ČASOPIS / GEOGRAPHICAL JOURNAL 73 (2021) 4, 375-391

DOI: https://doi.org/10.31577/geogrcas.2021.73.4.20

\title{
ASSESSMENT OF THE FLOOD RISK REDUCTION ALTERNATIVES IN MUNICIPALITIES OF THE UPPER MYJAVA AND TEPLICA RIVERS, SLOVAKIA
}

\author{
Lukáš Michaleje* \\ * Institute of Geography, Slovak Academy of Sciences, Štefánikova 49, Bratislava, Slovakia, \\ geoglumi@savba.sk
}

\begin{abstract}
Assessment of the flood risk reduction alternatives in municipalities of the upper Myjava and Teplica rivers, Slovakia

Flood risk management often uses multi-criteria analyses, which allow the most suitable alternatives for flood risk reduction to be chosen. We used the SAW (Simple additive weighting), AHP (Analytical hierarchy process) and TOPSIS (Technique for the order of preference by similarity to the ideal solution) methods to evaluate the alternatives in seven cadastral areas of the Upper Myjava and Teplica river basins. Economic, social, environmental, and technical criteria were chosen based on literature research. We compared the current situation (A0), alternatives proposed by watercourse administrators (A1), endangered inhabitants (A2), alternatives based on previous flood risk research (A3) and a combination of the previous (A5-A7). Most expensive alternatives include building new water structures, alternatives with lectures had the highest social impact and none of the alternatives had a significant effect on the environment. With three different sets of weights, we obtained 9 sets of results. In most cases, A3 was in the first place as the best alternative for flood risk reduction. With the TOPSIS method, the results were different. In cadastral areas where seven alternatives were compared, the A5 or A7 get first place. At the same time, we analysed the methods of selecting the most suitable alternative by watercourse managers, which showed a few shortcomings.
\end{abstract}

Key words: floods, flood risk management, multicriteria analysis, Myjava region

\section{INTRODUCTION}

Changes in the perception of flood risks have also provided an impulse for changes in their management system. From the concept of flood protection, there has been a gradual transition to integrated flood risk management (Brown and Damery 2002, Werritty 2006 and Liao 2014) which is based on a cycle that constantly re-evaluates the measures applied in order to improve preparedness for the next flood (IPCC 2012). The fulfilment of the management's main goal - the reduction of flood risk (Hooijer et al. 2004) - takes into account the long-term time horizon within the entire river basin (Sayers et al. 2013). The key principles of flood risk management are its complexity, decentralisation, participation, sustainability and equity. The complexity of flood risk management lies in considering flood risks and vulnerabilities while using a combination of strategies and measures to reduce them. The principle of decentralisation guarantees the division of management responsibilities into the national, regional and local levels. By involving several parties, especially vulnerable entities (residents, industry, agriculture), their needs are taken into account and the efficiency of management is increased (Dieperink et al. 2013). At the same time, flood risk management must take into account changing future conditions (Hooijer et al. 2004) and create sustainable 
measures. In addition to increasing the intensity and frequency of extreme precipitation and evapotranspiration in the river basin due to climate change (Fleming 2002 and IPCC 2007), land use and socio-economic changes must also be considered. The last aspect is equity. According to Penning-Rowsell and Priest (2015), funding for risk reduction measures can be set between all taxpayers and vulnerable entities. In the context of equity, it is also necessary to point out the allocation of resources. The same level of protection for all through structural measures is almost impossible. However, non-structural measures such as flood forecasting and warning systems, guidelines for development in floodplains, or compensation schemes are tools that make it easier to achieve this equity (Sayers et al. 2013).

In the context of the complexity of flood risk management, selecting the most appropriate alternative for flood risk reduction, while considering the interests of stakeholders, is a challenging task. The evaluation of alternatives thus creates a large space for decision-making (Jonkman et al. 2003). To support the transparency and objectivity of decision-making, decision support systems (DSSs) are used. Multicriteria analysis (MCA) belongs to such systems. Its main advantage is that it recognises the problem of choosing the most suitable alternative from several points of view, through different criteria (Gamper et al. 2006). The increasing popularity of MCA in flood risk management was covered in de Brito and Evers (2016). The paper summarizes that between the years 1995 to 2005 MCA was used in 128 peer-reviewed articles related to flood risk management. Most of them $(22.78 \%)$ were focused on ranking alternatives for flood mitigation.

Our paper aims to compare different alternatives for the reduction of flood risk in conditions of the specific hilly region of Myjava with high fluvial and pluvial flood risk. Sources of alternatives include proposals of watercourse managers, opinions of endangered inhabitant, previous research and their combination.

\section{DATA AND METHODS}

We obtained the parameters of the evaluated alternatives from publicly available sources or through consultations with experts. For the economic aspect of technical alternatives, we relied on the Flood Risk Management Plans in the Morava sub-basin (MŽP SR 2014), and the watercourse administrator - the Slovak Water Management Enterprise (SWME), PREFA Slovakia, and an expert assessment by Roman Krajčí from the Valabek Company. We calculated the price of sewerage and the sewage treatment plant construction was calculated as the average price of 15 projects completed in Slovakia. We drew this data from the Central Register of Projects (https://www.crp.gov.sk/). The price of alternatives in forests was calculated as the average price of these measures per $1 \mathrm{~km}^{2}$, while we obtained data from the Flood Risk Management Plans in the Morava sub-basin (Plans). The price of alternatives on agricultural land was expertly assessed by František Kadlček from 'Farm Čachtice'. The parameters of the social criterion were determined with our own expert estimate, as a percentage of the affected/participating population. The environmental criterion was based on the description of alternatives and their potential effect on ecosystems, soil degradation and reduction of water quality. Lastly, the impact on flood risk and vulnerability was based on the characteristics of the alternative. For example, a polder had a greater impact than watercourse maintenance.

A workflow is given in Fig. 1. For the evaluation of alternatives for flood risk reduction, we used four criteria: economic $(\mathrm{Ec})$, social $(\mathrm{S})$, environmental (En), and 
technical (T). Each criterion consists of several subcriteria (Tab. 1). When selecting the criteria, we used knowledge obtained from the literature.

Tab. 1. Criteria used in the assessment of flood risk reduction alternatives using multicriteria analysis

\begin{tabular}{|c|c|c|c|c|}
\hline Criterion & Subcriterion & Expression & Use in literature & Note \\
\hline \multirow{2}{*}{ Economic } & Price for alternative & quantitative & $\begin{array}{l}\text { Brouwer and van Ek } \\
\text { 2004, Kenyon } 2007\end{array}$ & $\begin{array}{l}\text { Financial costs associated with } \\
\text { the alternative implementation }\end{array}$ \\
\hline & $\begin{array}{l}\text { Price } \\
\text { for maintenance }\end{array}$ & quantitative & & $\begin{array}{l}\text { Financial costs of alternative } \\
\text { maintenance }\end{array}$ \\
\hline \multirow[b]{2}{*}{ Social } & $\begin{array}{l}\text { Number of affected } \\
\text { people }\end{array}$ & quantitative & De Bruijn 2005 & $\begin{array}{l}\text { Number of people affected } \\
\text { by the alternative }\end{array}$ \\
\hline & Participation & quantitative & $\begin{array}{l}\text { Foxon et al. 2002, Simo- } \\
\text { novic and Akter } 2006\end{array}$ & $\begin{array}{l}\text { Number of people involved } \\
\text { in the alternative }\end{array}$ \\
\hline \multirow{3}{*}{ Environmental } & $\begin{array}{l}\text { Number of affected } \\
\text { ecosystems }\end{array}$ & qualitative & $\begin{array}{l}\text { Markovic 2012, Penning } \\
\text {-Rowsell et al. } 2013\end{array}$ & $\begin{array}{l}\text { Number of affected parts } \\
\text { of the biosphere }\end{array}$ \\
\hline & Soil degradation & qualitative & $\begin{array}{l}\text { Bana e Costa et al. 2004, } \\
\text { Scolobig et al. } 2008\end{array}$ & $\begin{array}{l}\text { Alternative impact on soil } \\
\text { and runoff processes }\end{array}$ \\
\hline & Water quality & qualitative & $\begin{array}{l}\text { Bana e Costa et al. 2004, } \\
\text { Penning-Rowsell et al. } \\
2013\end{array}$ & $\begin{array}{l}\text { Alternative impact on the } \\
\text { physical, chemical, and } \\
\text { biological properties of water }\end{array}$ \\
\hline \multirow{3}{*}{ Technical } & $\begin{array}{l}\text { Impact on flood } \\
\text { hazard }\end{array}$ & qualitative & $\begin{array}{l}\text { Edjossan-Sossou et al. } \\
2014\end{array}$ & $\begin{array}{l}\text { Alternative effectiveness } \\
\text { in reducing flood risk }\end{array}$ \\
\hline & $\begin{array}{l}\text { Impact } \\
\text { on vulnerability }\end{array}$ & qualitative & $\begin{array}{l}\text { Edjossan-Sossou et al. } \\
2014\end{array}$ & $\begin{array}{l}\text { Alternative effectiveness } \\
\text { in reducing vulnerability }\end{array}$ \\
\hline & Lifetime & quantitative & Taib et al. 2016 & Lifetime of the alternative \\
\hline
\end{tabular}

The normalisation of the achieved values within the subcriteria was based on a maximum [1]:

$$
w_{i j}^{\prime}=\frac{w_{i j}}{w_{j}^{\max }},
$$

where $w_{i j}^{\prime}$ is the normalised value of the i-th value of the $j$-th criterion, $w_{i j}$ is the original value of the $i$-th value of the $j$-eth criterion, and $w_{j}^{\text {max }}$ is the largest value in the set of values of the $j$-th criterion. The values were in intervals $[0,1]$, where 0 represents the worst value and 1 the best. In the case of qualitative sub-criteria, we considered a rating of $(0-100)$, which we assigned with an expert assessment. We then normalised the values to the interval $[0,1]$ using formula [1] to make the subcriteria comparable. The next step involved the additive aggregation of subcriteria and their subsequent normalisation based on the range derived from formula [1]. We chose this step so that criteria with different amounts of subcriteria were comparable; Only two subcriteria were used for economic and social domains (range of values $(0-2)$ and three in the environmental and technical domains (range of values $0-3)$.

The economic and environmental criteria in their primary form are characterised by a negative impact; the alternative with the highest price or the most damaged environment would receive the best rating. Our intention was to minimise the cost of the measures and the environmental impact of the alternatives. For this rea- 
son, we "reversed" the values of the aggregate economic and environmental criteria (Fig. 1). This means that we subtracted the normalised values from the maximum value they could reach. We used pairwise comparison weighting to express the preference for the criteria, similar to the work of Bana e Costa et al. (2004), Shams et al. (2014) and Chitsaz and Banihabib (2015). Three sets of scales were created which allowed us to perform a sensitivity analysis.

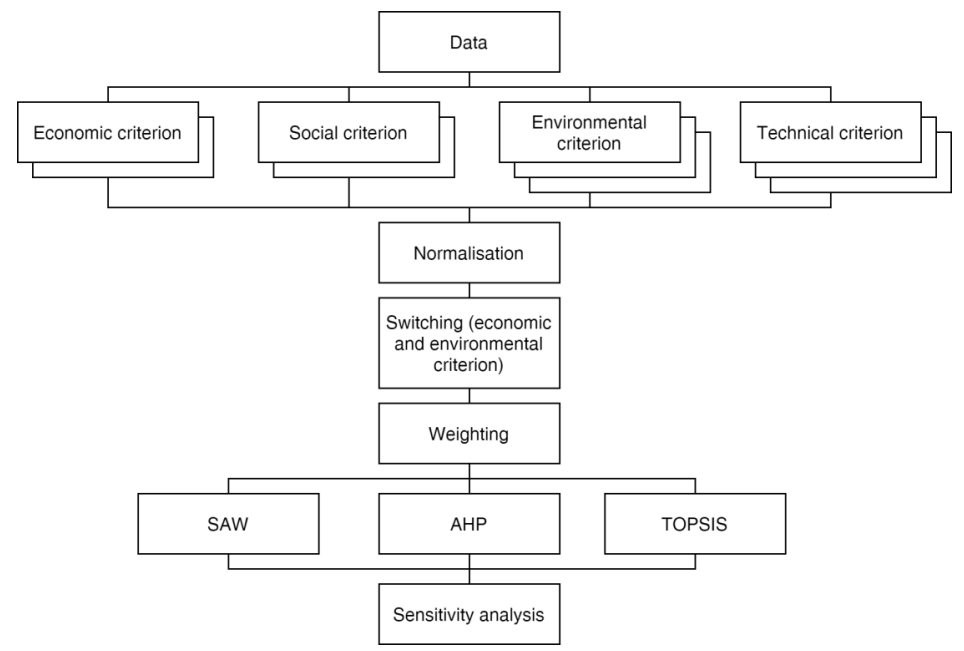

Fig. 1. Workflow for the evaluation of an alternative for flood risk reduction using multicriteria analysis

Subsequently, we applied three versions of multicriteria analyses (SAW, AHP and TOPSIS), as our intention was to compare individual decision rules and their impact on the results of the rank of alternatives.

\section{SAW - SIMPLE ADDITIVE WEIGHTING}

The simple additive weighting (SAW) method is one of the most widely used MCA methods and is also known as the scoring or weighted linear method (Malczewski 1999). It has been used in the works of Azibi and Vanderpooten (2003), Brouwer and van Ek (2004), Raaijmakers et al. (2008), Haque et al. (2012), Kang et al. (2013), van Loon-Steensma et al. (2014) and Chitsaz and Banihabib (2015). It is based on a formula [2], where we calculate the rank of alternatives $\left(A_{i}\right)$ as the weight of the $\mathrm{j}$-th criterion $\left(w_{j}\right)$ and the value of the $i$-th alternative of the $j$-th attribute $\left(x_{i j}\right)$ (Kang et al. 2013):

$$
A_{i}=\sum_{i=1}^{n} w_{j} x_{i j} .
$$

\section{AHP - ANALYTICAL HIERARCHY PROCESS}

This version of MCA was developed by Thomas L. Saaty in 1980 (Meyer et al. 2007). The first step involves creating a hierarchical structure of the problem with three levels: the main goal (zero level), the criteria (first level), and the alternatives 
(second level). At the first (alternatives) and the second (criteria) levels, a pairwise comparison is performed, which results in local priorities - weighing results. In the last step of this method, the ranking is determined based on the rating $\left(R_{i}\right)$, which is calculated using the formula [3] (Malczewski 1999):

$$
R_{i}=\sum_{k} w_{k} a_{i k}
$$

where $a_{i k}$ represents the result of the pairwise comparison of the $i$-th alternative and the $k$-th criterion and $w_{k}$ represents the result of the pairwise comparisons of the $k$-th criterion.

The final step of the AHP is the calculation of the consistency ratio $(C R)$. The calculation is based on formula [4] (Chitsaz et al. 2015):

$$
C R=C I / R I
$$

CI is index of consistency which can be calculated with formula [5] (Chitsaz et al. 2015):

$$
C I=\frac{\lambda_{\max }-n}{n-1}
$$

while $\lambda_{\max }=\sum s_{i k} a_{i k}$

where $n$ is the size of the value being compared and $s_{i k}$ represents the sum of the pairwise comparison matrix. The random index $(R I)$ was obtained from Tab. 2. If the $C R$ value was less than 0.1 , the evaluation was consistent.

Tab. 2. Random index values for the sizes of the compared file (Saaty 1980)

\begin{tabular}{ccccccccccc}
\hline$n$ & 1 & 2 & 3 & 4 & 5 & 6 & 7 & 8 & 9 & 10 \\
\hline$R I$ & 0 & 0 & 0.58 & 0.9 & 1.12 & 1.24 & 1.32 & 1.41 & 1.46 & 1.49 \\
\hline
\end{tabular}

\section{TOPSIS - TECHNIQUE FOR THE ORDER OF PREFERENCE} BY SIMILARITY TO THE IDEAL SOLUTION

This version of the MCA is based on the principle of ideal points (Malczewski 1999). It has been used in several works (Margeta and Knezic 2002, Nijssen et al. 2009, Schumann et al. 2010, Sahin et al. 2013, Shams et al. 2014 and Chitsaz and Banihabib 2015). In the first step of the method, ideal (maximum $-v_{+1}$ ) and negative (minimum $-v_{-1}$ ) values are determined for each criterion. The ideal point (maximum) is obtained by calculating the normalised maximum values of the criteria (vmaxn) [6] (Malczewski 1999).

$$
v+1=\left(v_{\max 1}+v_{\max 2} \ldots . v_{\operatorname{maxn}}\right)
$$

The calculation of the negative point is performed using formula [7] (Malczewski 1999), by substituting the normalised minimum values of the criteria $\left(\mathrm{v}_{\text {minn }}\right)$ :

$$
v+1=\left(v_{\min 1}+v_{\min 2} \ldots v_{\min \mathrm{n}}\right)
$$


To calculate the distance of alternatives from the ideal point $v_{+1}$ and the negative point $v_{-1}$ we used formulas [8] and [9] (Malczewski 1999), where $s_{i+}$ is the distance from the ideal point, $s_{i-}$ is the distance from the negative point, and $v_{i j}$ is the value of the $i$-th alternative in the $j$-th criterion:

$$
\begin{aligned}
& S_{i+}=\sqrt{\sum_{j=1}^{n}\left(v_{i j}+v_{+1}\right)^{2}} \\
& S_{i-}=\sqrt{\sum_{j=1}^{n}\left(v_{i j}+v_{-1}\right)^{2}}
\end{aligned}
$$

The ranking of alternatives is based on the proximity to the ideal point $c_{i+}$, which is in the range of the interval $[0,1]$. The closer the alternative is to one, the higher it's ranking. Proximity is calculated using the formula [10] (Malczewski 1999).

$$
c_{i+}=\frac{s_{i-}}{S_{i+}+S_{i-}}
$$

Uncertainty analysis was not performed as it is recommended when weights of criteria are obtained through stakeholders (Mosadeghi et al. 2012) and in our case the weight is determined by us. Uncertainties in the process of MCA are dealt with sensitivity analysis by changing weights (Porthin et al., 2013, Sahin et al. 2013, Su and Tung 2014 and Chitsaz and Banihabib 2015). We used three sets of weights for the sensitivity analysis. In the first set of weights, all the criteria had the same values. In the second and third sets, we determined the weights with the method of pair comparison. In this way, we were also able to compare versions of multicriteria analysis based on the variance of the results of the alternatives. As another way of comparison, we used Spearman's and Kendall's correlation coefficients.

\section{STUDY AREA}

The study area is located in the western part of Slovakia on the border of the Trnava and Trenčín NUTS 3 and includes the Brestovec, Myjava (Turá Lúka - part of Myjava), Podbranč, Sobotište, Stará Myjava, Vrbovce municipalities and covers an area of $167.19 \mathrm{~km}^{2}$ (Fig. 2). The main watercourses are the Myjava and Teplica rivers, which are of a rainy snow type. From a geological point of view, the studied area belongs to the flysch zone, consisting mainly of sandstones, claystones, and slums, which forms very low permeable soils. The study area has 17042 inhabitants living in Brestovec (945), Myjava (10 109), Podbranč (600), Sobotište (1485), Stará Myjava (733), and Turá Lúka (part of Myjava) (1631). A typical feature of this area is its dispersed settlement.

Past experiences with floods have resulted in the establishment of several flood risk reduction measures. The Brestovec reservoir has a retention volume of $134,444,000 \mathrm{~m}^{3}$ and Stará Myjava reservoir 13,600,000 $\mathrm{m}^{3}$. Polder Myjava and Svacenický stream are reservoirs with a retention volume of $113,460 \mathrm{~m}^{3}$, and 
$331,000 \mathrm{~m}^{3}$, respectively. Regulation of the Myjava river adjusted the river to flow Q100 $\left(48 \mathrm{~m}^{3} \cdot \mathrm{s}^{-1}\right)$. Several infiltration belts were excavated within the basin on the slopes around the villages and small dams were constructed on small streams.

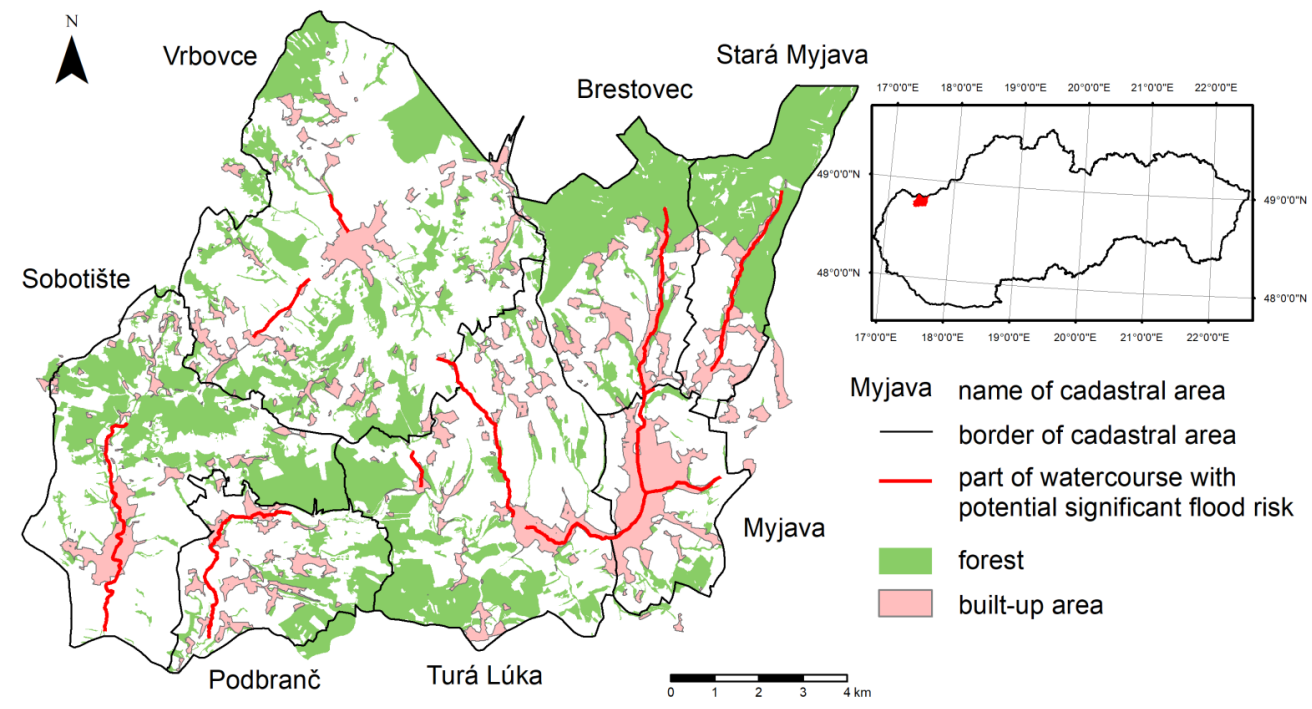

Fig. 2. Location of cadastral areas of the Upper Myjava and Teplice river basins and part of watercouses with a potentially significant flood risk

Floods are a common phenomenon, occurring mainly during the spring due to melting snow and precipitation. The plans identify ten sections with a potentially significant flood risk with a total length of $38.7 \mathrm{~km}$. The most serious floods occurred in 2005, 2006, and 2010. In 2005, 40 houses in Turá Lúka were flooded. During a flood in 2006 the water stage in Sobotište (river Teplica) reached $309 \mathrm{~cm}$ and the discharge was $37.19 \mathrm{~m}^{3} \cdot \mathrm{s}^{-1}$ which represents a T-year 20. In the Myjava (river Myjava) the water stage reached $168 \mathrm{~cm}$ and the discharge was $16.09 \mathrm{~m}^{3} . \mathrm{s}^{-1}$ which represents a T-year between 10 - 20 (SHMÚ 2006). More than 199 houses were flooded in 2006. Flooding in 2010 reached a water stage of $258 \mathrm{~cm}$ and a discharge of $27.75 \mathrm{~m}^{3} \cdot \mathrm{s}^{-1}$ which equals a T year 10 in Sobotište (river Teplica). In Myjava (river Myjava) water stage reached $121 \mathrm{~cm}$, a discharge of $8.54 \mathrm{~m}^{3} . \mathrm{s}^{-1}$ which is equal to T year $<5$. Damage in 2010 amounted to $610010 €$ when 18 houses were flooded. According to the results of the work by Solín et al. (2017), in addition to fluvial flood hazards, pluvial flood hazards are also typical in this area. Pluvial floods are caused by the saturation of the river basin with precipitation, as water begins to flow down the slope (saturation excess overland flow), or when the high rainfall intensity exceeds the infiltration capacity of the soil (infiltration excess overland flow).

We have identified at least four alternatives for each municipality:

- The zero alternative represents the status quo as a reference for comparison with other alternatives. 
- The first alternative is based on the plans and preventive measures proposed based on the zoning plans of the municipalities. These should be applied to water sections with a potentially significant flood risk (Fig. 2).

- The second alternative is based on the opinions of the residents, which we obtained in 2016 through a questionnaire survey. Question were used in Michaleje et al (2015) and Solín et al. (2017 and 2018). Residents, as direct recipients of risk, have the best knowledge about their surroundings, as well as the course of floods. Their knowledge is therefore an essential part of flood risk management. Based on the answers of the population, we created an alternative for flood risk management assessments. In the questionnaire, we asked for information on the early warning of the population, obstacles in watercourses, and opinions on the effectiveness of technical measures, secondary factors contributing to floods, and specific proposals for reducing flood risk.

- The third alternative is based on flood risk assessments which have been carried out in previous works (Michaleje et al. 2015, Solín et al. 2017 and 2018).

In the case of a high flood risk, which is determined by several factors, we created other alternatives as a combination of the previous three alternatives. All the measures under each alternative are listed in Tab. 3 .

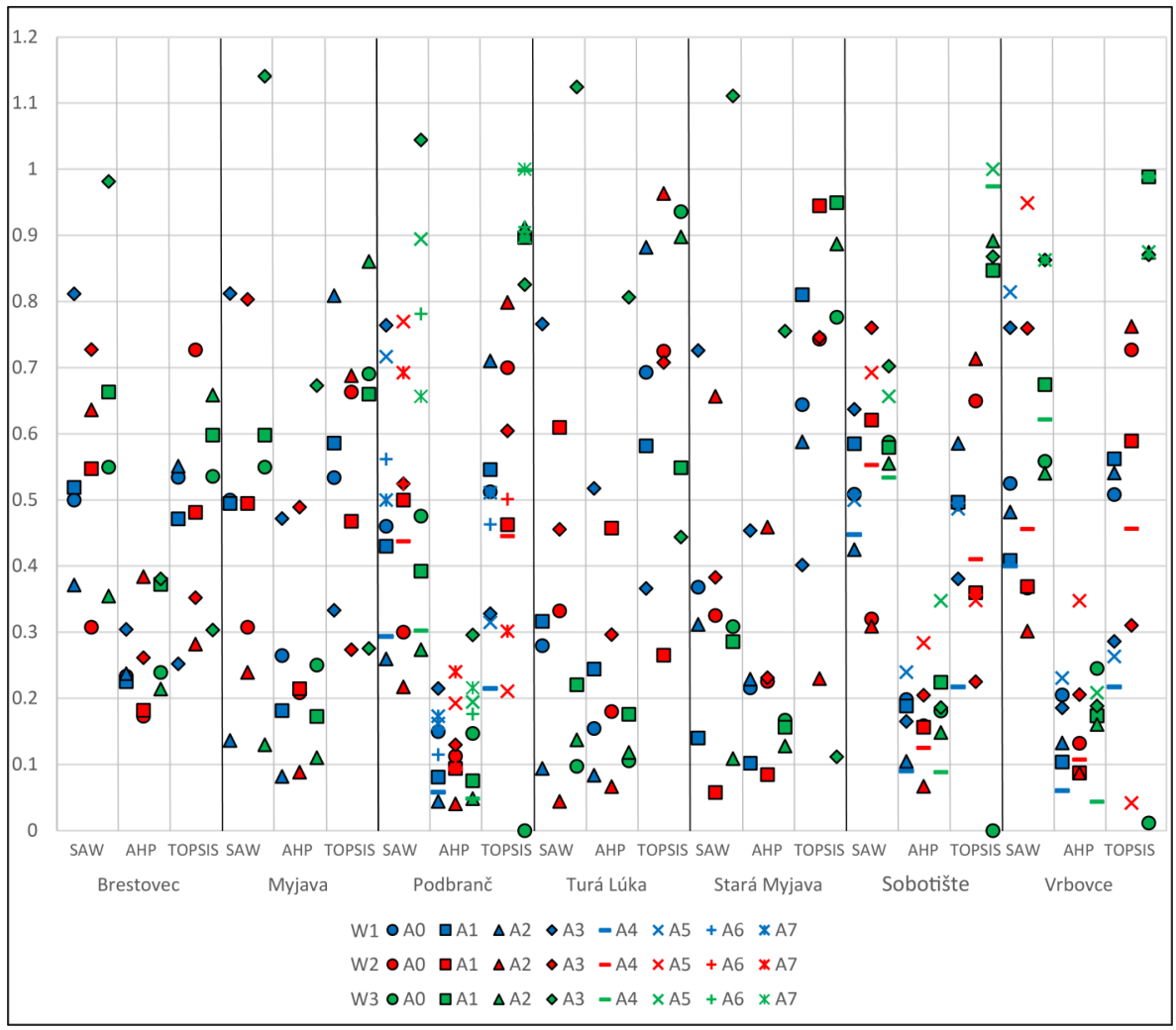

Fig. 3. Comparison of the variance of the results of the multicriteria analysis methods in the cadastral areas of the Upper Myjava and Teplice river basins

(W1, W2, W3 - weights, A0, A1, .., A7 - alternatives) 
GEOGRAFICKÝ ČASOPIS / GEOGRAPHICAL JOURNAL 73 (2021) 4, 375-391

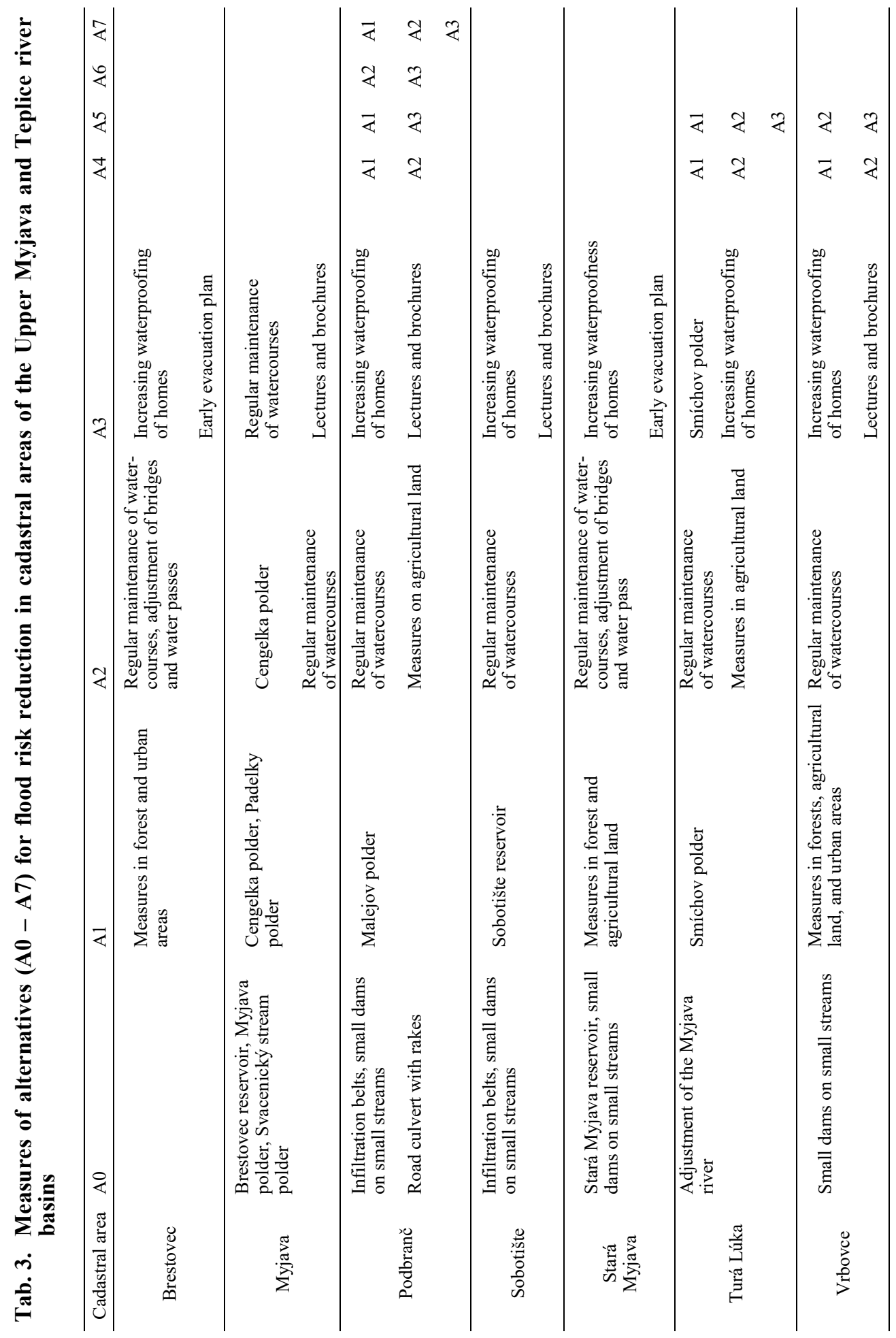




\section{RESULTS}

The most expensive alternatives are those with measures from the category of water structures (VN Sobotište - $28599354 €$, polder in Myjava - $7025725 €$, and polder in Podbranč - $4126402 €$ ). The cheapest are the 0 alternatives, which have no investment or maintenance requirements (Brestovec $-0 €$, Podbranč $2000 €)$. In the social criterion, the combination of alternatives with measures of the nature of water structures and education of the population or evacuation had the greatest impact on the population. Participation was relatively low in almost all the alternatives.

In the environmental criterion, we did not notice any significant interventions in nature. Nonetheless the most affected ecosystems would be the watercourses, agricultural land, meadows and floodplains. Soil and water quality were also little affected. The biggest impact on water quality was in the case of water structures (water reservoir, polders, reconstruction of bridges).

Most of the alternatives were aimed at reducing the flood hazard, with the exception of educating the population and early evacuation, which mainly affected vulnerability. Water structures achieved a higher reduction of flood hazards. The reduction of flood hazards and vulnerability was achieved by a combination of measures aimed at reducing these risk components. The lifetime of the alternatives was divided into the short-term (maintenance of watercourses), medium-term (education, waterproofing measures) and long-term (water structures) measures.

By applying three decision rules for three sets of scales, we created 9 combinations of results for seven cadastral areas. The ranking of alternatives in individual cadastral areas is shown in Fig. 3. In Brestovec, Myjava, Sobotiště, and Stará Myjava, in most cases the third alternative (A3) came first. An exception were the results obtained with the TOPSIS method, where this alternative reached the last place. The results were affected by the functioning of this method. The A3 alternative also predominated in Podbranč, but with the second set of scales in SAW and AHP, alternatives A5 and A7 took first place. The resulting ranking of alternatives in Tura Luka was no longer as clear-cut as in previous cases. In Vrbovce, the fifth alternative took first place in five variations. Sensitivity analyses verified the robustness of the methodology used. The ranking of the alternatives did not change in many cases, but the overall score of the alternatives indicates a change in the resulting values (Fig. 3).

We used the Spearman and Kendall correlation coefficients to compare the different methods of multicriteria analyses (Tab. 4). We considered the results from Podbranč, which with eight alternatives represented the longest series. The Spearman's correlation coefficient indicated a high correlation between the SAW and AHP, and SAW and TOPSIS methods. The pairs of SAW and TOPSIS methods, respectively AHP and TOPSIS point to little to no correlation. We observed similar results with the Kendeall correlation coefficient. 
Tab. 4. Comparison of the multicriteria analysis methods using the Spearman and Kendall correlation coefficients

\begin{tabular}{cccccc}
\hline & & \multicolumn{2}{c}{ Spearman correlation coefficient } & \multicolumn{2}{c}{ Kendall correlation coefficient } \\
\cline { 3 - 6 } & & AHP & TOPSIS & AHP & TOPSIS \\
\hline \multirow{2}{*}{ Weights 1} & WSM & 0.714286 & -0.47619 & 0.571429 & -0.5 \\
& AHP & - & -0.16667 & - & 0.0 \\
\multirow{2}{*}{ Weights 2} & WSM & $\mathbf{0 . 8 5 7 1 4 3}$ & $\mathbf{- 0 . 8 3 3 3 3}$ & 0.678571 & -0.71429 \\
& AHP & - & -0.7619 & - & -0.57143 \\
\multirow{2}{*}{ Weights 3} & WSM & 0.52381 & 0.047619 & 0.428571 & 0.178571 \\
& AHP & - & -0.40476 & - & -0.25 \\
\hline
\end{tabular}

\section{DISCUSSION}

The use of a multicriteria analysis to evaluate flood risk reduction alternatives is very common (de Brito and Evers 2016). The selection of decision criteria is the most important step in the whole analysis. Ahmarisharaf et al. (2015), Ghanbarpour et al. (2013) and Kang et al. (2013) used only technical criteria and alternatives with structural measures such as dams, levees, and watercourse modifications. Other works (Akter and Simonovic 2005, Kenyon 2007 and Ceccato et al. 2011) have used social and environmental criteria evaluated by stakeholders, in addition to technical and economic criteria. In our opinion, the evaluation made by experts makes more sense, as they are capable of professionally assessing the given criterion. Such an approach was chosen by Margeta and Knezic (2002), Haque et al. (2012), and Taib et al. (2016). However, the most appropriate method of assessing alternatives to reduce flood hazard involves a combination of expert assessments of quantitative criteria and modelling of qualitative criteria (Brouwer and van Ek 2004, Evers et al. 2012 Almoradie et al. 2015 and Chitsaz and Banihabib 2015).

The evaluation of alternatives for flood risk reduction in the Slovak Republic is presented in the plans. Evaluation of alternatives were made in the studied area for the cadastral areas of Myjava (Cengelka stream and Smíchovský stream), Podbranč (Myjava river), Sobotište (Teplica river), and Turá Lúka (Hukov stream). In the introduction, three alternatives were characterised: zero (original state), the first and the second alternatives (Tab. 5). For the structural measures (dams and polders) detailed technical information is provided (slope of the dam, material used for construction, width of the dam, etc.). In the case of the second alternatives, the characteristics were only general and information is missing, e.g., about the length of the forest transport network or the length of anti-erosion belts and the types of perennial or permanent crops.

The evaluation was divided into three parts. The first part provides brief information on the positive and negative impacts of the alternatives. The following part evaluates the alternatives in terms of their environmental impact, which contains six components: 1) impact on the population, 2) impact on the urban complex and land use, 3) impact on sectors of economic activity, 4) impact on cultural and historical monuments and cultural heritage, 5) impact on protected areas, and 6) other impacts on the environment. Points from 0 to 10 can be awarded in each component, with more points indicating a more negative impact. The results of this evalu- 
ation are the sum of the points. The scale divides the environmental impact according to Tab. 6 .

Tab. 5. overview of assessed alternatives from the plans (MESR 2014)

\begin{tabular}{llll}
\hline Area & $\begin{array}{l}\text { Zero } \\
\text { alternative }\end{array}$ & First alternative & Second alternative \\
\hline Myjava (Cengelka) & Original state & Padelky polder & $\begin{array}{l}\text { Measures in forests and maintenance } \\
\text { of watercourses }\end{array}$ \\
$\begin{array}{l}\text { Myjava (Smíchovský s.) } \\
\text { Podbranč (Myjava) }\end{array}$ & $\begin{array}{l}\text { Original state } \\
\text { Original state }\end{array}$ & $\begin{array}{l}\text { Smíchov polder } \\
\text { Malejov polder }\end{array}$ & $\begin{array}{l}\text { Measures in forests and agricultural land } \\
\text { Myjava river regulation }\end{array}$ \\
Sobotište (Teplica) & Original state & Sobotište reserovir & $\begin{array}{l}\text { Measures in forest, agricultural land, } \\
\text { maintenance of watercourses }\end{array}$ \\
Turá Lúka (Hukov s.) & Original state & Padelky polder & \\
\hline
\end{tabular}

Tab. 6. Scale of the impact of alternatives on the environment (MESR 2014)

\begin{tabular}{ll}
\hline Classification of impact significance & Sum of points \\
\hline $0-$ very low impact & points $<=12$ \\
1 - low impact & $12<$ points $<=24$ \\
$2-$ medium impact & $24<$ points $<=36$ \\
$3-$ significant impact & $36<$ points $<=48$ \\
$4-$ very significant impact & points $>48$
\end{tabular}

The third part of the evaluation dealt with the financial aspect of the alternatives. It provides information on the total costs of preparation, implementation, operation, maintenance, and repair during the lifetime of the alternative. In this respect, a high disparity was observed between the price of the Sobotište reservoir (28 $599354 €$ ) and the potentially prevented damage (4 $164588 €$ ). The conclusion of the assessment combines the previous sections into the Assessment of an Environmentally Better Alternative, which is within the ordinal scale: a very good alternative (1), a good alternative (2), and a moderately good alternative (3). However, it was not clear how the sub-evaluations were aggregated into the final assessment of the environmentally better alternative.

Methodology of assessment alternatives to flood risk reduction described in the Plans is sign that a change is gradually taking place in the field of flood risk management in the Slovak Republic. The introduction of Directive 2007/60/EC on the assessment and management of flood risks into the legal system of the Slovak Republic brought certain elements of flood risk management. However, some aspects are still neglected and more appropriate ways of assessing and managing flood risks need to be pointed out.

\section{CONCLUSION}

In our work, we compared alternatives for flood risk reduction in the cadastral areas of six municipalities in Western Slovakia in the Upper Myjava and Teplice river basins. The area is characterised by a specific dispersed settlement and a high 
flood risk. To evaluate alternatives, we chose three versions of multicriteria analysis: SAW, AHP, and TOPSIS. The zero alternative represented the reference state, and the first alternative was based on the Flood Risk Management Plan prepared by SWME. The second alternative considered the proposals of residents and the third alternative was based on previous work on flood risk assessments in this area. In most cases, the third alternative was in the first place, with the exception of the TOPSIS method, which determines the rank of alternative based on the proximity to the ideal point and distance from the negative point. We performed the sensitivity analysis by applying three sets of scales, which confirmed the robustness of the methods. A comparison of multicriteria analysis methods by the Spearman and Kendall correlation coefficient showed a correlation between the SAW and AHP, and SAW and TOPSIS. The analysis of applied flood risk management in the studied area pointed out shortcomings in the evaluation carried out by SWME. There is lack of information on non-structural alternatives and there is also no clear way to aggregate sub-evaluations.

This research was supported by the Science Grant Agency (VEGA) of the Ministry of Education, science, research and sport of the Slovak Republic and the Slovak Academy of Sciences No. 02/0086/21 Assessment of the impact of extreme hydrological phenomena on the landscape in the context of a changing climate.

\section{REFERENCES}

AHMADISHARAF, E., KALYANAPU, A. J., CHUNG, E. S. (2015). Evaluating the effects of inundation duration and velocity on selection of flood management alternatives using multi-criteria decision making. Water Resources Management, 29, 25432561. DOI: https://doi.org/10.1007/s11269-015-0956-4

AKTER, T., SIMONOVIC, S. P. (2005). Aggregation of fuzzy views of a large number of stakeholders for multi-objective flood management decision-making. Journal of Environmental Management, 77. 133-143. DOI: https://doi.org/10.1016/j.jenvman.2005. 02.015

ALMORADIE, A., CORTES, V. J., JONOSKI, A. (2015). Web-based stakeholder collaboration in flood risk management. Journal of Flood Risk Management, 8, 19-38. DOI: https://doi.org/10.1111/jfr3.12076

AZIBI, R., VANDERPOOTEN, D. (2003). Aggregation of dispersed consequences for constructing criteria: The evaluation of flood risk reduction strategies. European Journal of Operational Research, 144, 397-411. DOI: https://doi.org/10.1016/S0377-2217 (01)00400-3

BANA E COSTA, C. A., SILVA, P. A., CORREIA, F. N. (2004). Multicriteria evaluation of flood control measures: the case of Ribeira do Livramento. Water Resources Management, 18, 263-283. DOI: https://doi.org/10.1023/B:WARM.0000043163.19531.6a

BROUWER, R., van EK, R. (2004). Integrated ecological, economic and social impact assessment of alternative flood control policies in the Netherlands. Ecological Economics, 50, 1-21. DOI: https://doi.org/10.1016/j.ecolecon.2004.01.020

BROWN, J. D., DAMERY, S. L. (2002). Managing flood risk in the UK: Towards an integration of social and technical perspectives. Transactions of the Institute of British Geographers, 27, 412-426. DOI: https://doi.org/10.1111/1475-5661.00063

CECCATO, L., GIANNINI, V., GIUPPONI, C. (2011). Participatory assessment of adaptation strategies to flood risk in the Upper Brahmaputra and Danube river basins. Environmental Science and Policy, 14, 1163-1174. DOI: https://doi.org/10.1016/ j.envsci.2011.05.016

De BRITO, M. M., EVERS, M. (2016). Review article: Multi-criteria decision making for flood risk management: A survey of the current state-of-the-art. Natural Hazards and 
Earth System Sciences Discussions, 16, 1019-1033. DOI: https://doi.org/https:// doi.org/10.5194/nhess-16-1019-2016

De BRUIJN, K. M. (2005). Resilience and flood risk management: A systems approach applied to lowland rivers. Delft (Delft University Press). DOI: https://doi.org/ISBN: 90407-2599-3

DIEPERINK, C., GREEN, C., HEGGER, D., DRIESSEN, P., BAKKER, M., van RIJSWICK, M., CRABBE, A., EK, K. (2013). Flood risk management in Europe: Governance challenges related to flood risk management. Utrecht (STAR-FLOOD Consortium).

EDJOSSAN-SOSSOU, A. M., DECK, O., AL HEIB, M., VERDEL, T. (2014). A decisionsupport methodology for assessing the sustainability of natural risk management strategies in urban areas. Natural Hazards and Earth System Sciences, 14, 3207-3230. DOI: https://doi.org/10.5194/nhess-14-3207-2014

EVERS, M., JONOSKI, A., MAKSIMOVIČ, C., LANGE, L., OCHOA RODRIGUEZ, S., TEKLESADIK, A., CORTES AREVALO, J., ALMORADIE, A., EDUARDO SIMÕES, N., WANG, L., AKROPOULOS, C. (2012). Collaborative modelling for active involvement of stakeholders in urban flood risk management. Natural Hazards and Earth System Science, 12, 2821-2842. DOI: https://doi.org/10.5194/nhess-12-28212012

FLEMING, G. (2002). Learning to live with rivers - the ICE's report to government. Civil Engineering, 150, 15-21. DOI: https://doi.org/10.1680/cien.150.1.15.38541

FOXON, T. J., MCILKENNY, G., GILMOUR, D., SOUTER, N., BUTLER, D., PEARSON, P., JOWITT, P., MOIR, J. (2002). Sustainability criteria for decision. Support in the UK water industry. Journal of Environmental Planning and Management, 45, 285301. DOI: https://doi.org/10.1080/0964056022011634

GAMPER, C. D., THÖNI, M., WECK-HANNEMANN, H. (2006). A conceptual approach to the use of cost benefit and multi criteria analysis in natural hazard management. Natural Hazards and Earth System Science, 6, 293-302. DOI: https://doi.org/10.5194/ nhess-6-293-2006

GHANBARPOUR, M. R., SALIMI, S., HIPEL, K. W. (2013). A comparative evaluation of flood mitigation alternatives using GIS-based river hydraulics modelling and multicriteria decision analysis. Journal of Flood Risk Management, 6, 319-331. DOI: https:// doi.org/10.1111/jfr3.12017

HAQUE, A. N., GRAFAKOS, S., HUIJSMAN, M. (2012). Participatory integrated assessment of flood protection measures for climate adaptation in Dhaka. Environment and Urbanization, 24, 197-213. DOI: https://doi.org/10.1177/0956247811433538

HOOIJER, A., KLIJN, F., PEDROLI, G. B. M., van OS, A. G. (2004). Towards sustainable flood risk management in the Rhine and Meuse river basins: Synopsis of the findings of IRMA-SPONGE. River Research and Applications, 20, 343-357. DOI: https:// doi.org/10.1002/rra.781

CHITSAZ, N., BANIHABIB, M. E. (2015). Comparison of different multi criteria decision -making models in prioritizing flood management alternatives. Water Researches $M a$ nagement, 29, 2503-2525. DOI: https://doi.org/10.1007/s11269-015-0954-6

IPCC (2007). Climate change 2007: Synthesis report. Geneva (IPCC). DOI: https:// doi.org/10.1256/004316502320517344

IPCC (2012). Managing the risks of extreme events and disasters to advance climate change adaptation. New York (Cambridge). DOI: https://doi.org/10.1017/CBO978 1139177245

JONKMAN, S. N., van GELDER, P. H. A. J. M., VRIJLING, J. K. (2003). An overview of quantitative risk measures for loss of life and economic damage. Journal of Hazardous Materials, 99, 1-30. DOI: https://doi.org/10.1016/S0304-3894(02)00283-2

KANG, B., LEE, J. H., CHUNG, E. S., KIM, D., KIM, Y. DO. (2013). A sensitivity analysis approach of multi-attribute decision making technique to rank flood mitigation projects. KSCE Journal of Civil Engineering, 17, 1529-1539. DOI: https://doi.org/10.1007/ s12205-013-0360-7 
KENYON, W. (2007). Evaluating flood risk management options in Scotland: A participant-led multi-criteria approach. Ecological Economics, 64, 70-81. DOI: https:// doi.org/10.1016/j.ecolecon.2007.06.011

LIAO, K. H. (2014). From flood control to flood adaptation: A case study on the Lower Green River Valley and the City of Kent in King County, Washington. Natural Hazards, 71, 723-750. DOI: https://doi.org/10.1007/s11069-013-0923-4

MALCZEWSKI, J. (1999). GIS and multicriteria decision analysis (1st ed.). New York (Wiley).

MARGETA, J., KNEZIC, S. (2002). Selection of the flood management solution of karstic field: Vrgorsko polje case study. Water International, 27, 431-441. DOI: https:// doi.org/10.1080/02508060208687022

MARKOVIC, M. (2012). Multi criteria analysis of hydraulic structures for river training works. Water Resources Management, 26, 3893-3906. DOI: https://doi.org/10.1007/ S11269-012-0110-5

MEYER, V., HAASE, D., SCHEUER, S. (2007). GIS-based multicriteria analysis as decision support in flood risk management. UFZ Discussion Papers, 6. Helmholtz-Zentrum für Umweltforschung, Leipzig.

MICHALEJE, L., SOLIN, L', MADAJOVÁ, M. (2015). Percepcia povodňového rizika obyvatel'mi a jej postavenie v právnom systéme Slovenska: Prípadová štúdia v povodí hornej Myjavy. Geografický Časopis, 68, 228-243.

MOSADEGHI, R., WARNKEN, J., TOMLINSON, R., MIRFENDERESK, H. (2012). ncertainty analysis in hte application of multicriteria deciion-making methods in Australian strategic environment decision. Journal of Environmental Planning and Management, 56, 1097-1124. DOI: https://doi.org/10.1080/09640568.2012.717886

MŽP SR (2014). Plán manažmentu povodňového rizika v čiastkovom povodí Moravy. Bratislava (Ministerstvo životného prostredia SR), [Online]. Available: http:// www.vuvh.sk/rsv2/default.aspx?pn=PMPRI [accessed 25 October 2021].

NIJSSEN, D., SCHUMANN, A., PAHLOW, M., KLEIN, B. (2009). Planning of technical flood retention measures in large river basins under consideration of imprecise probabilities of multivariate hydrological loads. Natural Hazards and Earth System Science, 9, 1349-1363. DOI: https://doi.org/10.5194/nhess-9-1349-2009

PENNING-ROWSELL, E. C., YANYAN, W., WATKINSON, A. R., JIANG, J., THORNE, C. (2013). Socioeconomic scenarios and flood damage assessment methodologies for the Taihu Basin, China. Journal of Flood Risk Management, 6, 23-32. DOI: https://doi.org/10.1111/j.1753-318X.2012.01168.x

PENNING-ROWSELL, EDMUND C., PRIEST, S. J. (2015). Sharing the burden of increasing flood risk: Who pays for flood insurance and flood risk management in the United Kingdom. Mitigation and Adaptation Strategies for Global Change, 20, 9911009. DOI: https://doi.org/10.1007/s11027-014-9622-z

PORTHIN, M., ROSQVIST, T., PERRELS, A., MOLARIUS, R. (2013). Multi-criteria decision analysis in adaptation decision-making: A flood case study in Finland. Regional Environmental Change, 13, 1171-1180. DOI: https://doi.org/10.1007/s10113-0130423-9

RAAIJMAKERS, R., KRYWKOW, J., van der VEEN, A. (2008). Flood risk perceptions and spatial multi-criteria analysis: An exploratory research for hazard mitigation. Natural Hazards, 46, 307-322. DOI: https://doi.org/10.1007/s11069-007-9189-z

SAHIN, O., MOHAMED, S., WARNKEN, J., RAHMAN, A. (2013). Assessment of sealevel rise adaptation options: Multiple-criteria decision-making approach involving stakeholders. Structural Survey, 31, 283-300. DOI: https://doi.org/10.1108/SS-01-20130006

SAYERS, P, LI, Y., GALLOWAY, G., PENNING-ROWSELL, E., SHEN, F., KANG, W., YIWEI, C., QUESNE, T. LE. (2013). Flood risk management: A strategic approach. Paris (UNESCO), [Online]. Available: http://www.sayersandpartners.co.uk/uploads/ 6/2/0/9/6209349/flood-risk-management-web.pdf [accessed 25 October 2021]. 
SCHUMANN, A. H., NIJSSEN, D., PAHLOW, M. (2010). Handling uncertainties of hydrological loads in flood retention planning. International Journal of River Basin Management, 8, 281-294. DOI: https://doi.org/10.1080/15715124.2010.512561

SCOLOBIG, A., BROTO, V. C., ZABALA, A. (2008). Integrating multiple perspectives in social multicriteria evaluation of flood-mitigation alternatives: The case of Malborghetto-Valbruna. Environment and Planning C: Government and Policy, 26, 1143-1161. DOI: https://doi.org/10.1068/c0765s

SHAMS, F., MOHAMED, S., FAYEK, A. R. (2014). Improving consistency evaluation in fuzzy multi-attribute pairwise comparison-based decision-making methods. Asia-Pacific Journal of Operational Research, 31(4), 1-23. DOI: https://doi.org/10.1142/S0217 595914500249

SHMÚ (2006). Povoden̆ na Morave na prelome apríla a mája 2006. Bratislava (Slovenský hydrometeorologický ústav).

SIMONOVIC, S. P., AKTER, T. (2006). Participatory floodplain management in the Red River Basin, Canada. Annual Reviews in Control, 30, 183-192. DOI: https://doi.org/ 10.1016/j.arcontrol.2006.05.001

SOLÍN, L., SLÁDEKOVÁ MADAJOVÁ, M., MICHALEJE, L. (2017). Flood hazards in the headwaters area: Lessons learned from a survey of households in the upper Myjava basin, Slovakia. Water Policy, 19, 1081-1096. DOI: https://doi.org/10.2166/wp.2017. 008

SOLÍN, L., SLÁDEKOVÁ MADAJOVÁ, M., MICHALEJE, L. (2018). Vulnerability assessment of households and its possible reflection in flood risk management: The case of the upper Myjava basin, Slovakia. International Journal of Disaster Risk Reduction, 28, 640-652. DOI: https://doi.org/10.1016/j.ijdrr.2018.01.015

SU, H.-T., TUNG, Y.-K. (2014). Multi-criteria decision making under uncertainty for flood mitigation. Stochastic Environmental Research and Risk Assessment, 28, 1657-1670. DOI: https://doi.org/10.1007/s00477-013-0818-7

TAIB, C. M. I. C., YUSOFF, B., ABDULLAH, M. L., WAHAB, A. F. (2016). Conflicting control project. Group Decision and Negotiation, 25, 157-180. DOI: https:// doi.org/10.1007/s10726-015-9437-7

Van LOON-STEENSMA, J. M., SCHELFHOUT, H. A., VELLINGA, P. (2014). Green adaptation by innovative dike concepts along the Dutch Wadden Sea coast. Environmental Science and Policy, 44, 108-125. DOI: https://doi.org/10.1016/j.envsci. 2014.06.009

WERRITTY, A. (2006). Sustainable flood management: Oxymoron or new paradigm? Area, 38, 16-23. DOI: https://doi.org/DOI: 10.1111/j.1475-4762.2006.00658.x

https://www.crp.gov.sk/

Lukášs Michaleje

\section{HODNOTENIE ALTERNATÍV NA REDUKCIU POVODŇOVÉHO RIZIKA V OBCIACH POVODIA HORNEJ MYJAVY A TELPICE, SLOVENSKO}

Manažment povodňového rizika ponúka cyklus neustáleho prehodnocovania a optimalizácie opatrení na d’alšie povodňové udalosti. Opiera sa o princípy komplexnosti, decentralizácie, participácie, udržatel’nosti a spravodlivosti. Pri rozhodovaní o najvhodnejšej alternatíve na redukciu povodňového rizika využíva najčastejšie multikriteriálnu analýzu, ktorá poskytuje hodnotenie alternatív z viacerých, často protichodných hl'adísk.

Ciel'om nášho príspevku je hodnotenie viacerých alternatív na redukciu povodňového rizika pomocou multikriteriálnej analýzy v obciach povodia hornej Myjavy a Teplice. Zvolili sme tri verzie multikriteriálnej analýzy SAW (Simple additive weighting), AHP (Analytical hierarchy process) a TOPSIS (Technique for the order of preference by simila- 
rity to the ideal solution). SAW predstavuje jednoduchú metódu, ktorá násobí hodnotenie jednotlivých kritérií váhami. Metóda AHP využíva párové porovnanie medzi alternatívami. TOPSIS určuje poradie alternatív na základe ich vzdialenosti od ideálneho a opačného, nedokonalého bodu. Zo študovanej literatúry sme vybrali štyri najpoužívanejšie kritériá: ekonomické, sociálne, environmentálne a technické. Studované územie sa vyznačuje vysokým povodňovým rizikom a povodne sú tu častým javom. V každom zo siedmich katastrálnych území sme porovnávali súčasný stav (A0), alternatívy navrhnuté správcom vodných tokov (A1), alternatívy navrhnuté ohrozenými obyvatel'mi (A2) a alternatívy, ktoré vyplývajú $\mathrm{z}$ výsledkov predchádzajúceho výskumu hodnotenia povodňového rizika (A3). V obciach s vysokým a komplexným povodňovým rizikom sme kombinovali jednotlivé alternatívy. Vo väčšine prípadov sa na prvom mieste umiestnili alternatívy A3, okrem metódy TOPSIS a obcí, kde bol viac alternatív ako štyri. Napriek tomu bolo celý proces citlivý na zmenu váh a alternatívy pri hodnotení v rôznych metódach a váhach nedosahovali rovnaké hodnoty. Analýza hodnotenia alternatív správcom vodných tokov poukázala na nedostatky v informáciách o všetkých alternatívach, ale aj o spôsobe agregácie čiastkových hodnotení. 
